\title{
J.E.T.T. UPDATES
}

\section{TANDBERG OFFERS PANASONIC VIDEO EQUIPMENT}

In response to the increasing demand for multimedia learning centers, Tandberg Educational, Inc. has reached an agreement with National Panasonic to add Panasonic video products to the Tandberg line of audio and computer equipment.

Tandberg Educational, recognized as the world's largest manufacturer of high quality language laboratories, can now offer Panasonic video monitors, cameras, videotape players, and other video equipment to provide a complete multi-media center.

Tandberg Educational recently introduced its unique video distribution system. This system allows a teacher to distribute four separate videos from the console to the student positions and keep track of each student's progress through the video from a monitor at the console. Tandberg's video distribution system combined with Panasonic video equipment will give educators the most advanced technology available.

"Educators do not like to go to one vendor for audio equipment, another for video, and a third for computers. They want a turn-key service," says Tandberg President, Erik Moseby. "At Tandberg, we have always been sensitive to the needs of educators. We are pleased that we can now offer this total service."

CONTACT TANDBERG EDUCATIONAL AT (800) 367-1137

\section{SONY ANNOUNCES NEW PROGRAM LOADING UNIT FOR ITS ZL-10 SYSTEM}

Sony announces the availability of a program loading unit, the ZL-10L1 for its ZL-10 Language Laboratory system. The ZL-10L1 provides four times normal speed loading, saving, and master tape copying in an easy to operate unit. Using the ER-4061 master recorders, the ZL-10L1 will enable the ZL-10 System to speed preparation, and will make language classes much more effective. Features of the ZL-10L1 include the following:

Four Times Normal Speed Loading: Two programs can be loaded into the $\mathrm{ZL}-10 \mathrm{C1} / \mathrm{C} 2$ simultaneously.
Four Times Normal Speed Saving: Two programs can be saved into two ER-4061's simultaneously.

Four Times Normal Speed Master Tape Copying

Skip Monitor: ON: The loading and saving programs can be monitored for one second at normal speed every other three seconds; OFF: The loading and saving programs can be entirely monitored at normal speed. 
Student Drill Rec in Program 1 and Program 2: This function makes all student units begin DRILL REC. After eight seconds, the ER-4061's automatically record student voices in the voice memory at four times normal speed.
Student Voices Saving in Program 1 and Program 2: The ER-4061's record student voices in the voice memory at four times normal speed.

CONTACT SONY AT 1 (800) 344-1201.

\section{SONY EXPANDS DEALER NETWORK}

Sony of America is pleased to announce that two new Language Learning Systems dealers have joined the dealer network under Cetek, Inc., the East Coast Distributor for Sony language laboratory products and associated audio visual equipment. The new dealers are:

Audio Visual Concepts, Inc. 106 Isabel Andreu Aguilar Hato Rey, Puerto Rico 00918 (809) 753-7700

Contact: Manuel Frias, Jr.
Industrial Communications and Electronics, Inc. 6727 Complex Drive, Suite B

Baton Rouge, Louisiana 70809

(504) 292-5617

Contact: Larry Howard

Industrial Communications (Florida Office)

P.O. Box 9223

Fort Meyers, Florida 33902

(800) 344-1201

Contact: Lynn Orosz

\section{RESEARCH DESIGN ASSOCIATES, INC. UPDATES ITS OFFERINGS}

RDA/Mind Builders is now the largest publisher/distributor of interactive ESL software in the United States. The company is proud to announce the publication of its 1989 catalog, dedicated solely to ESL and sent free upon request to all educators. There are many new titles, including the entire line of interactive MS DOS CALL software from Eurocentres in Zürich, Switzerland. The new titles are vastly improved versions of the popular Apple titles from Wida software including STORYBOARD, CHOICEMASTER, TESTMASTER, GAPMASTER, MATCHMASTER, PINPOINT, VOCAB, and WORDSTORE. All of the programs have complete authoring, on-line help, and the kind of interactivity which is the hallmark of all RDA Products. Educators can also receive free demo versions by writing to RDA at 10 Boulevard Avenue, Greenlawn, NY 11740 or calling toll-free 1-800-654-8715.

In addition, RDA is now publishing updated and improved versions of the popular RHUBARB, MARK-UP, SEQUITUR, and DOUBLE UP by John and Muriel Higgins. Purchasers of the older versions can receive the updates free by writing to RDA and including $\$ 10.00$ for postage, handling, and shipping.

Finally, RDA is now moving into the Macintosh environment with the publication of its first Mac program, MACLANG. MACLANG is an easy to use, interactive authoring system that allows language teachers to quickly and easily 
produce CALL materials on the Macintosh. MACLANG offers teachers the possibility of using English (and graphics) and Japanese Kana, French, German, Italian, Russian, Greek, Turkish, Spanish, Romanian, or Portuguese. The program has five exercise formats and options that allow immediate feedback, error correction, and positive reinforcement. MACLANG lessons can also be constructed using the Tandberg tape recorder for listening comprehension, sound discrimination drills, or vocabulary exercises. Preview copies are now available from RDA.

CONTACT RDA AT 1 (800) 654-8715.

\title{
EVALUATION AND RESEARCH IN EDUCATION
}

\section{The Durham and Newcastle Research Review}

\author{
Chairman: A. D. Edwards Managing Editor: Roy Bevan \\ Review Editor: Michael S. Byram
}

Editorial Board:

Madeleine Atkins, Roger Barnes, Frank Coffield, Carol FitzGibbon, Richard Gott, John McGuiness, D. R. McNamara, Bill Mittins, Beverley Shaw, David Westgate.

Advisory Board:

Eileen M. Byrne, W. B. Dockrell, Larry V. Hedges, John Heywood, Günter Kutscha, Roland Oullet.

Statistical Adviser: Richard Boys.

The aim of the Journal is to make methods of evaluation and research in education available to teachers, administrators and research workers.

Papers published in the Journal will do one or more of the following:

(1) Report evaluation and research findings;

(2) Treat conceptual and methodological issues;

(3) Consider the implications of the above for action.

There is an extensive Book Reviews section and also occasional reports on educational materials and equipment.

\section{Multi-site field trials}

One major innovation is a regular section edited by Carol FitzGibbon providing instruments that teachers and others doing research might use. This section will also provide ideas for collaborative small scale research.

Volume 3 (1989) 3 issues

Libraries $£ 25.00$ (US $\$ 55.00$ )

Individuals $\mathrm{f} 9.00$ (US\$20.00)

Students $\mathrm{f6.00}$ (US\$14.00)

Payment may be made by

ACCESS/MASTERCARD/EUROCARD/AMERICAN EXPRESS/DINER'S CARD

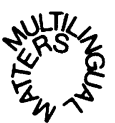

MULTILINGUAL MATTERS LTD

Bank House, 8a Hill Road, Clevedon Avon, England, BS21 7HH

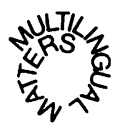

